\title{
National Parliaments in the post-Lisbon European Union: Bureaucratization rather than Democratization?
}

Thomas Christiansen, Anna-Lena Högenauer

\& Christine Neuhold 
This online paper series is published by the

Observatory of Parliaments after the Lisbon Treaty (OPAL).

OPAL is a scientific consortium comprising researchers from four partner institutions:

Maastricht University

SciencesPo.

畻圈 UNIVERSITY OF

University of Cologne

OPAL Online Papers are published at www.opal-europe.org.

Series Editors: Thomas Christiansen \& Ariella Huff

ISBN: 978-90-8|88|3-7-| 


\title{
National Parliaments in the post-Lisbon European Union: Bureaucratization rather than Democratization?'
}

\author{
Thomas Christiansen, Anna-Lena Högenauer \& Christine Neuhold
}

\begin{abstract}
Much of the discussion about the provisions on national parliaments in the Lisbon Treaty has concerned the potential for increasing politicization and parliamentarization of EU politics. However, a more immediate change can be expected at the domestic level, as national parliaments adapt to make effective use of these new powers. In order to approach this question systematically, this article develops a framework for the analysis of the Europeanization of national parliaments that starts from the recognition that the Lisbon changes involve an inherent dynamic towards increasing transnational interaction among parliaments as well as pressures to rely more on technical expertise and administrative support in their internal workings. The processes of transnationalization and bureaucratization are considered as key indicators that help us to identify different degrees of Europeanization of national parliaments in the EU. As a final step, the article develops a typology of national parliaments based on the assumption that the more Europeanised parliaments will tend to invest more into their administrative resources and will engage to a greater extent with other national parliaments as well as with EU-level actors. The conceptual framework developed here is designed to facilitate systematic empirical research into the Europeanization of national parliaments.
\end{abstract}

Key words: European Integration, Europeanization, Bureaucratization, Transnationalization, National Parliaments, Lisbon Treaty

\footnotetext{
${ }^{1}$ This paper has been accepted for publication in 2013 as an article in Comparative European Politics.
} 


\title{
National Parliaments in the post-Lisbon European Union: Bureaucratization rather than Democratization?
}

\author{
Thomas Christiansen, Anna-Lena Högenauer \& Christine Neuhold
}

\section{Introduction}

Much of the discussion of the Lisbon Treaty has been about its potential to enhance the politicization and parliamentarization of European Union (EU) politics, in particular in the wake of the expansion of the powers of the European Parliament (EP) and the introduction of elements of participatory democracy through the European Citizens Initiative. In the same vein of bringing Europe closer to the citizens, the role of national parliaments in EU decision-making has also been upgraded: these have acquired new powers to review and object to draft legislative acts, building on earlier provisions introduced by the Maastricht and Amsterdam treaties as well as on the Barroso initiative that followed the failed ratification of the Constitutional Treaty (Kaczynski, 2011). This gradual expansion of powers has been reflected in the scholarly debate. Following accounts of how parliaments were the "victims" of European integration due to a process of "deparliamentarization" (Moravcsik, 1995; Norton, 1996; Weber-Panariello, 1995) in the 1990s, national parliaments have been portrayed as more active players in the context of EU integration after the Treaty of Amsterdam (e.g. Auel and Benz, 2005; O'Brennan and Raunio, 2007), although some still raise the question as to whether national parliaments are "losers or late-comers" (Maurer and Wessels, 2001) or indeed whether they are "destined for irrelevance" (Raunio, 2010).

In this context, attempts have also been made to classify national parliaments according to their formal-legal powers and to explain variation across the EU with regard to the way in which the executive can be held to account (Maurer and Wessels, 2001; Kiiver, 2006). The introduction of the 'Open Method of Coordination' (Benz, 2007; de Ruiter, 2010) and recent reforms through treaty change have opened up new areas of research (e.g. Cooper, 2006; Cooper, 2012; Raunio, 2007; Rothenberger and Vogt, 2007; Kiiver, 2011; Kiiver, 2012).

Unlike most of these previous contributions, this article focuses not on the influence that national parliaments may or may not have at the EU level, but on the reverse: it addresses the question whether and how the new opportunities arising from the Lisbon Treaty change the practices and procedures of national parliaments. The wider issue here is the possible transformation of parliamentary practice in the European Union, and the eventual move towards a - however imperfect - multilevel democracy in the European Union. Addressing these questions is an empirical challenge (and one that will be addressed in forthcoming publications; see Heffner et al, 
2014 and Christiansen, Högenauer and Neuhold, 2014), but first of all it requires the development of conceptual and analytical frameworks in order to study these potential domestic changes systematically.

With this aim in mind, the present article proposes a conceptual framework designed to identify if and how EU level changes impact on the national level. The framework, as developed in the subsequent sections of this article, is based on three initial assumptions are derived from our preliminary research. First, we start from the recognition that the vertical process of national parliaments needing to 'digest' and respond to initiatives from 'Brussels' is an elementary feature of the evolving system. While this vertical dynamic concerning pressures from the EU level is evident and immediate, our second assumption concerns the horizontal dynamic which is more of an indirect result of the need for parliaments to coordinate their scrutiny activities in order to make effective use of the post-Lisbon Early Warning System. This involves a new intensity in the networking among national parliaments - one that builds on, but goes beyond, pre-existing interparliamentary cooperation and which includes networking with EU institutions.

The third assumption goes beyond the existing focus on the (party) political and deliberative dynamics by acknowledging in the importance of the administrative dimension. While much of what has been done by and through formal institutions has been dominated by the political preferences of elected members, political party hierarchies, parliamentary speakers and committee chairs, we consider it important to take the potential input of administrators into the internal handling of EU affairs and inter-parliamentary cooperation seriously.

The proposed framework for the analysis of national parliaments in the post-Lisbon EU therefore relies on the following key elements:

- $\quad$ first, a process of Europeanization of national parliaments, indicating the potential changes within domestic arrangements, procedures and resource allocations in response to developments at the European level;

- $\quad$ second, a process of transnationalization, being concerned with the potential intensification of contacts through transnational networks of policy-makers from national parliaments and EU institutions; and

- third, a process of bureaucratization, resulting from the potential for administrative players playing a significantly greater role with respect to the internal handling of EU affairs in national parliaments and the development of transnational networks.

In the following we will fully explicate each of these processes individually and establish possible linkages between them. In particular, we advance the argument that the Europeanization triggered by the Lisbon Treaty not only has impacts on domestic structures and procedures, but 
leads, as a corollary, to processes of transnationalization and bureaucratization. This argument is based on the observation that the effective use of the new powers pushes national parliaments, on the one hand, to cooperate better with each other (transnationalization), and, on the other hand, to rely to a greater extent on technical expertise in EU-related matters (bureaucratization).

Building on this recognition of the linkages between the three processes, the final objective of the conceptual development proposed here is to identify the degree to which different national parliaments are subject to Europeanization on the basis of the degree of the bureaucratization and transnationalization that can be observed in their work. In other words, we argue that the more "Europeanised" parliaments tend to invest more into the provision of administrative resources for European affairs and engage to a greater extent with their counterparts in other member states as well as with EU-level actors.

This article proceeds in the following section to set the scene by outlining the new provisions on national parliaments in the Lisbon Treaty, before then developing in greater detail the conceptual framework for the study of national parliaments in the EU. This involves, as a first step, the discussion of the three key concepts of Europeanization, transnationalization and bureaucratization and their inter-linkages in greater depth, followed by a typology of national parliaments in the EU on the basis of the preceding discussion. By way of conclusion, we spell out the implications - and the need - for further empirical research in this area, and also highlight the significance of such findings in terms of the wider normative debate about European democracy.

\section{National Parliaments in the Lisbon Treaty}

As a result of concerns about a 'democratic deficit' of the EU, the issue of national parliaments was included in the Laeken Declaration as one of the key priorities to be considered by the Convention on the Future of Europe (European Council, 2001). Following the negotiations in both the Convention and the subsequent Intergovernmental Conferences, stipulations on enhancing the role of national parliaments were first enshrined in the Constitutional Treaty and later taken over virtually unchanged into the Lisbon Treaty (Raunio, 2007; Kiiver, 2012: 20).

The new provisions most likely to affect the day-to-day functioning of national parliaments are the right of national parliaments to receive all Commission consultation documents, all instruments of legislative planning and all draft legislative acts that are sent to the EP and to the Council as well as the agendas and minutes of Council meetings (Article 1 and article 2 of Protocol on the role of national parliaments), and the mechanism called the "Early Warning System" (EWS). Under this mechanism, any chamber of a national parliament may, within eight weeks from the date of transmission of a legislative act in the official languages of the Union, send to the 
Presidents of the EP, the Council and the Commission a reasoned opinion stating why it considers that the draft in question does not comply with the principle of subsidiarity. Each national parliament has two votes and in the case of bicameral systems, each of the two chambers has one vote. Where reasoned opinions on non-compliance with the principle of subsidiarity represent at least one third of all the votes allocated to national parliaments, the draft must be reviewed (also called "yellow card" procedure). ${ }^{\mathrm{i}}$ The institution that has put forward the proposal may maintain, amend or withdraw the draft and has to justify the decision. If, under the ordinary legislative procedure, the reasoned opinions represent at least a simple majority of the votes, the Commission has to issue a reasoned opinion if it decides to maintain the proposal (so-called "orange card" procedure). In that case, if, by a majority of $55 \%$ of the members of the Council or a simple majority of the votes cast in the EP, the legislator is of the opinion that the proposal does not comply with the principle of subsidiarity, the draft shall be given no further consideration (COSAC, 2008: 23-24; Kiiver, 2012 27-31). ${ }^{\text {ii }}$

The powers conferred by the Treaty on national parliaments are narrowly circumscribed in terms of a 'subsidiarity check' and in part depend on the support of at least one EU institution. Nevertheless, national parliaments have obtained for the first time a formal role in EU policymaking. As the effective use of these powers is expected to require adaptation, we seek to understand what impact these reforms will have on the functioning of national parliaments and to what extent this will lead to genuine Europeanization.

\section{Conceptualising the Impact of the Lisbon Treaty Reforms on National Parliaments}

\section{The Process of Europeanization}

The concept of Europeanization is a late-comer in European integration research. Until the early 1990s, the literature largely focused on the bottom-up process of the pooling of sovereignty and failed to address the top-down impact of European institutions and policies. This tendency is reflected in some of the definitions of Europeanization (cf. Risse et al, 2001). Nevertheless, the predominant use of the concept today is either top-down or circular, i.e. that domestic actors attempt to influence European policies and institutions that in turn influence domestic actors (cf. Börzel, 2002; Radaelli, 2003). In line with the top-down focus of this article, Ladrech's classical definition of Europeanization as "a process reorienting the direction and shape of politics to the degree the EU political and economic dynamics become part of the organizational logic of national politics and policy-making" (1994: 69) will be retained for its clear lines of causality. 
The existing literature on the Europeanization of national parliaments documents that the role, functioning and organization of national parliaments have changed, mostly by focusing on the establishment and powers of European Affairs Committees and changing procedures (e.g. Norton, 1996; Hansen and Scholl, 2002; Dimitrakopoulos, 2001; Auel, 2006; Holzhacker, 2007). Sectoral committees have received much less attention (Raunio and Wiberg, 2009: 75). While the need to look at the role of sectoral committees in EU affairs was recognized over a decade ago (e.g. Raunio, 1999: 186) genuine empirical interest in sectoral committees is relatively recent (e.g. Raunio and Wiberg, 2009). Another aspect that has been overlook is the adaptation of administrative support structures.

In examining the degree of Europeanization of national parliaments after Lisbon, two questions arise: Are all actors equally willing to adapt? And will all actors have the capacity to adapt (in equal measure)? The answers to these questions matter, because the new powers acquired by national parliaments are ultimately meaningful only to the extent to which they can actually be wielded. This is particularly pertinent in the case of the EWS, where the influence of national parliaments depends on their ability to reach a certain threshold of votes. What matters is not so much the individual capacity of national parliaments to act on EU legislative proposals, but their ability to collectively respond through the EWS mechanism. If a significant number of chambers are unwilling or unable to be involved in the process, this negatively affects the ability of the remaining chambers to issue a yellow or orange card. We therefore need to understand the circumstances under which Europeanization of national parliaments is likely to occur.

In its explanation of the dynamics of domestic adaptation, the Europeanization literature generally draws on a mix of institutionalist explanations. The core assumption is that adaptational pressures occur if there is 'misfit' between European requirements and domestic policies, procedures or institutions (Börzel and Risse, 2003). From an actor-centred institutionalist perspective, change can be the result of changes in the power balance between domestic actors (Auel, 2005). From a sociological institutionalist perspective, regular interaction between actors can alter their beliefs and perspectives thereby changing their strategies (Knill and Lehmkuhl, 2002: 260).

The literature has interpreted the shift towards executive dominance as a result of European integration as an instance of 'misfit' (Auel, 2005: 307). The scrutiny activities of national parliaments and attempts to mandate national parliaments can be interpreted as an attempt to regain influence. The Lisbon Treaty has created new opportunities for participation that can contribute toward reducing this misfit. However, they can only be used effectively if national parliaments address two challenges: firstly, they have to reorganise their internal procedures and resources in a way that allows them to filter a vast amount of highly technical legislation, and, 
secondly, they have to cooperate with other parliaments on legislation of interest to them in order to obtain the required number of votes to issue a yellow or orange card under the EWS. Until such an adaptation has taken place, a gap between what is possible according to the Treaty and what is feasible will persist. More concretely, we expect the adaptation to involve both the bureaucratization and transnationalization of the work of national parliaments (see following sections).

However, there are a number of intervening factors, mostly related to the domestic context, that influence the willingness and ability of a national parliament to change. For example, using Hansen and Scholl's useful distinction between constitutional misfit (e.g. formal scrutiny systems), functional misfit (e.g. for speaking parliaments) and cultural misfit (depending on adversarial or cooperative cultures) (Hansen and Scholl, 2002:3-6), one could argue that working parliaments can adapt much more easily to the challenge of scrutinising large numbers of documents under the EWS than speaking parliaments.

Some institutionalist interpretations of the Europeanization process suggest convergence, as institutions in a shared environment are expected to adopt similar solutions in their quest to optimise their processes (Harmsen, 1999: 84). Convergence can also result from the imitation of the effective responses of others (Kassim, 2003: 89). Frequent interaction can lead to the emergence of similar perceptions among actors (Olsen, 1997: 161). In the case of national parliaments, we do indeed expect that all parliaments experience processes of bureaucratization and transnationalization as a result of European influences. Similarly, the increased workload is likely to give rise to a greater involvement of sectoral committees, replacing the past 'monopoly' of European Affairs Committees (EACs) over EU affairs. In the Netherlands and the Czech Republic, for example, specialized committees are starting to assume "responsibility" for EU policies that fall into their domain.

At the same time, both sociological and rational choice institutionalist approaches foresee continued divergence. Pre-existing structures and values can lead to different interpretations of challenges (March and Olsen, 1984), and different starting points can lead to different costbenefit ratios.

Overall, variation in the adaptation of national parliaments to the Lisbon provisions is likely to occur in the extent to which national parliaments bureaucratise and transnationalise their work, rather than in the underlying direction of this change. Existing qualitative research has identified a host of potential factors, but in the absence of systematic data across a large number of cases - an essential research agenda for the future - it is difficult to identify the factors that are truly significant for the adaptation of national parliaments to the Lisbon provisions. Based on insights from the existing literature on variation and characteristics of national parliaments in EU affair 
scrutiny (e.g. Raunio, 2009; Damgaard and Jensen, 2005; Laursen, 2005; Kaczynski, 2011) and the initial findings of our own research, we advance the following propositions:

- In line with path-dependency, parliaments that have strong mandating powers are less likely to focus their attention on the EWS. For example, the Nordic parliaments can mandate their national governments in EU matters, which reduces the misfit between the parliaments' powers in domestic policy-making and their powers in European policy-making and thus the incentive to invest in the EWS compared to national parliaments that cannot mandate their ministers. We would therefore expect mandating parliaments to prioritise mandating over the EWS. By contrast, second chambers, which are often relatively weak even in domestic politics, are expected to see the Lisbon changes as an opportunity to carve a role for themselves.

- The extent of the Europeanization of a parliament is expected to depend on its resources. Thus, the parliaments of smaller countries with fewer financial resources may not only be at a disadvantage due to the EACs size but also due to staff resources. In the case of the latter, the financial crisis may provide a further barrier to an increase in resources.

- $\quad$ Parliaments in countries with majority governments and strong party discipline are expected to be less likely to adapt, as the majority party avoids open conflicts with its government. By contrast, parliaments in countries with minority governments or low party discipline are expected to be particularly active.

Any given parliament may, of course, be subject to several reinforcing or conflicting factors.

The next two sub-sections will elaborate on the two key aspects of the Europeanization process: bureaucratization and transnationalization. Particular attention will also be paid to how these phenomena can be measured, with a view to developing a typology of national parliaments.

\section{The Process of Transnationalization}

The EWS grants powers not so much to individual parliaments as it does to the collectivity of national parliaments in the EU. The system of yellow or orange cards is only activated by the 'vote' of a relevant number of national chambers (Cooper, 2012). Successful adaptation to this system therefore requires a transnationalization of parliamentary work, which refers to both a strengthening of the horizontal interaction among national parliaments and of the vertical interaction between parliaments (collectively and individually) and EU level actors. Such interaction is important, if not essential, in order to exchange substantive and procedural information, to form an agreed view of the way in which the principle of subsidiarity should be understood and applied, and subsequently to coordinate which legislative proposals should be 
'targeted' for review and what mechanisms should be set up in order to exchange information and views among the actors involved (cf. Cooper, 2006, 2012).

To a certain extent, this challenge ties in with long-standing structures for inter-parliamentary cooperation that form an important basis for adaptation since the Lisbon Treaty. However, in our view, it captures only a part of the wider phenomenon of transnationalization: transnationalization needs to capture not only the formal and informal interaction among MPs, but also the cooperation that occurs among civil servants, parliamentary officials, legal advisers and committee clerks.

On the political level, formal cooperation involves, as mentioned above, the use of institutionalised arenas such as COSAC (Conference of Parliamentary Committees for Union Affairs of Parliaments of the European Union), IPEX - the information exchange database through which documents concerning legislative scrutiny are transmitted (www.ipex.eu) - or the conference of parliamentary speakers. COSAC in particular, representing EACs, is a key player both for information exchange on scrutiny and for the exchange of best practice. However, alongside these formal and institutionalised mechanisms, the importance of informal contacts between MPs, often along party-lines, should not be neglected (Miklin and Crum, 2011).

In addition, our preliminary research has shown that a significant part of interaction among national parliaments, and with the European Parliament, is conducted through officials rather than elected politicians, and it is considered important that this dimension is part of the analytical frame (cf. Högenauer and Neuhold, 2012). The permanent representatives of national parliaments in Brussels (NPRs) in particular have arguably been playing a crucial role in coordinating national positions since the launch of the EWS, communicating issues raised in one member state's chamber to the members in other member states (Hoegenauer and Neuhold, 2012). Practically all member states have now an NPR resident in Brussels, with most bi-cameral parliaments having one representative for each chamber. A majority of the representatives are parliamentary career civil servants and have a comprehensive insight into their respective legislative system. The NPRs have their offices in close proximity to each other on the premises of the EP - a practical aspect which is both the sign of, and cause for, close cooperation among them. One key tool are the so-called 'Monday morning meetings' which regularly bring together the NPRs in order to exchange information and coordinate their (parliaments') actions especially when it comes to the EWS. This largely informal and administrative channel has so far been more significant in terms of transnationalization than the activities of political decision-makers, who have shown only a limited willingness to engage with the new system (Kaczynski, 2011: 15).

Our conception of transnationalization thus goes beyond the traditional idea of interparliamentary cooperation, with its emphasis on formal arenas providing the meeting place for 
elected politicians. From this starting point, we propose to differentiate between different degrees of transnationalization by categorising the activity of national parliaments as being either 'low', 'medium' or 'high' (see Table 1).

\begin{tabular}{|l|l|}
\hline $\begin{array}{l}\text { Degree of } \\
\text { Transnationalisation }\end{array}$ & Indicators \\
\hline Low & $\begin{array}{l}\text { Occasional and essentially informal contacts with other NPs or } \\
\text { European actors; dominant focus of the work of the NP on } \\
\text { mandating the national government }\end{array}$ \\
\hline Hedium & $\begin{array}{l}\text { Regular participation in institutionalised contact with other NPs } \\
\text { and/or European actors through mechanisms such as COSAC, IPEX, } \\
\text { NPR meetings, attendance of interparliamentary committee meetings; } \\
\text { provision of information to other NPs and European actors (e.g. } \\
\text { reasoned opinions on IPEX) }\end{array}$ \\
\hline High & $\begin{array}{l}\text { Intensive and constant level of contacts with other NPs and } \\
\text { European actors; active provision of information; active cooperation } \\
\text { with other actors (e.g. active discussion of legislation or a common } \\
\text { approach, alerting others to legislation and reacting to the } \\
\text { information provided by others). }\end{array}$ \\
\hline
\end{tabular}

Table I The Transnationalisation of National Parliaments after Lisbon

To a certain extent, assessing the degree of transnationalization of national parliaments can rely on the quantitative study of participation in formal interparliamentary meetings, visits to other parliaments and visits from foreign actors. Informal contacts can also be quantified, although this is likely to be more methodologically challenging and may have to rely on survey methods or interviews. However, in addition to this, the approach of parliaments can be studied qualitatively, for example by determining whether a parliament merely reacts to proposals from elsewhere, or whether (and to what extent) it also initiates such cooperation itself.

In the empirical research that will need to be done based on this conceptual framework, the following developments with regard to the transnationalization of parliamentary work might be observed:

- The adaptation to the EWS may lead to an increased transnationalization of parliamentary work and a strengthening of existing institutions of cooperation, such as COSAC or the Monday morning meetings of NPRs.

- For the most active participants in the EWS, this may also lead to more informal transnational contacts with a wider range of actors, such as MPs from specialised committees 
(which now play a greater role in the scrutiny of European legislation) and committee officials.

- A multi-level web of interaction among parliamentary representatives at the EU, the national and regional level may emerge.

However, given the dynamic linkages between all three processes identified at the outset, the extent of transnationalization of individual parliaments will also depend on the factors identified with respect to the processes of Europeanization and bureaucratization.

\section{The Process of Bureaucratization}

In the modern, liberal welfare state, parliamentarians cannot make all policy decisions themselves. Simple time-limits, lack of technical expertise and other limitations make it obvious that elected policy-makers must delegate some of their decision-making authority to assistants, administrative officials (Arnold, 1987: 279). Why legislatures would delegate and how they can cope with the effects of this process has been extensively studied in the context of the US Congress (e.g. Moe, 1990: 223; McCubbins and Schwartz, 1984; Gailmard, 2002). ${ }^{\text {iii }}$ These studies from the US Congress reflect that the delegation of powers to civil servants is "often a concession to expertise" and although procedures of retaining administrative control might have been carefully designed they are far from perfect (Gailmard and Patty, 2007: 536)

Our conceptualization of bureaucratization is based on the definition by Morgan and Perry, who define national service systems as "mediating institutions that mobilize human resources in the service of the affairs of a state." (Morgan and Perry, 1998; in: Van den Berg, 2011: 413). We expand this concept by focusing on human resources that serve not only the state in a narrow sense but also include parliaments and do not merely focus on national systems but also on actors that work within an increasing transnational arena. The EWS requires national parliaments to scrutinise an increased volume of documents within a short period of time and to draw up draft opinions. We thus expect those parliaments that wish to use it actively and effectively to increase the size and adapt the role of their bureaucracies, and thus mobilise more human resources, in order to be able to respond to the challenge. While there is hardly any research on the role and the nature of parliamentary administration, linkages can be made to the general literature on bureaucracies. From a conceptual angle one can i.a. discern attempts to observe the "effects" of Europeanization on national administrations from a comparative perspective - in the vein of identifying analytical arrangements that distinguish different administrative systems - and to search for possible effects of Europeanization on national executives (i.e. Knill, 2001; Goetz, 200o). 
Empirical research sheds light on what bureaucrats actually do and how this relates to instructions from their political masters. In this context Page and Jenkins identify three types of policy roles for middle-level bureaucrats in the UK:

- $\quad$ a production role when drawing up policy drafts and documents,

- $\quad$ a maintenance role in tending to- and managing policies, and

- $\quad$ a service role in offering knowledge and skills to a particular person or body on a continual basis (Page and Jenkins, 2005: 60-75).

The administrative base of the European Parliament (EP) has until recently been practically ignored in the scholarly debate. Neunreither can be seen as a pioneer in this context, giving a comprehensive insight into the role that administrative staff play within the EP and providing a historical overview from the 1950 until around 2005 (Neunreither, 2006). More recent research ranges from the assessment that administrators within the EP can be reduced to mere "paperkeepers" (Winzen, 2011: 41), to the observation that these are in fact players that can assume a steering role in the EU policy-process, i.e. influence the direction that process is taking (Dobbles and Neuhold, 2012). Egeberg (et al) (2012) find, when examining the activities of EP staff by way of an online survey, that the activities of these actors mainly revolve around expert and sectoral concerns.

As alluded to above, the role of bureaucrats within national parliaments within the European system of governance has been largely absent from the scholarly debate. An exception in this context is Baron (2012) who stresses that the within the French national assembly the sole access route to the parliamentary public service is that of an anonymous exam, the so-called 'concours'. This is seen to guarantee the independence of civil servants vis-à-vis parliamentarians. French civil servants have the duty to be neutral in the "Weberian sense" and thus cannot assume executive functions (Baron, 2012). Clearly, further research into the actual practice of parliamentary bureaucracy across the EU will be needed in order for us to develop a better understanding of the way in which national parliaments can handle the new challenges arising with Lisbon.

As discussed in the previous section, not all national parliaments will be equally interested in the EWS. However, those that seek to use it effectively are likely to see the following changes:

- Due to the sheer bulk of EU legislation, the pre-selection of which documents are to be submitted to subsidiarity control will be conducted by bureaucratic actors;

- $\quad$ Parliaments with administrations that have hitherto been subject to strict neutrality rules are less likely to delegate tasks to the administration than parliaments with a tradition of administrative advice. The role of bureaucrats will thus vary across EU Member States from 
performing a production-role to a service-role. One might even go as far as assuming that in some member states civil servants (will) fulfil a role which could be classified as a 'steering role'. For the EWS this could imply that administrators (pre-)select legislative acts that are to be submitted to a subsidiarity check.

- $\quad$ Now that the Lisbon Treaty is in force, bureaucratic players will cooperate increasingly in order to alert other parliaments as regards to those pieces of legislation which give rise to subsidiarity concerns within their respective system.

- As mentioned in the section on Europeanization, smaller or poorer countries may experience less bureaucratization due to budgetary constraints.

Thus, taking into account that national parliaments will experience different degrees of Europeanization, the impact on the role of parliamentary bureaucracies can be captured as follows:

\begin{tabular}{|l|l|}
\hline $\begin{array}{l}\text { Degree of } \\
\text { Bureaucratization }\end{array}$ & Indicators: Role of Staff \\
\hline Low & Procedural advice, organization of meetings \\
\hline Medium & Service role: offering advice to MPs and committees \\
\hline High & $\begin{array}{l}\text { Service and emergent steering role: Devolution of responsibilities } \\
\text { from MPs/committees to civil servants, e.g. pre-sampling of legislation, } \\
\text { drafting of opinions/resolutions; role in interparliamentary } \\
\text { cooperation }\end{array}$ \\
\hline
\end{tabular}

Table 2 The Bureaucratisation of National Parliaments after the Lisbon Treaty

In order to research these questions within the practical political process, this requires the study of the process of European affairs scrutiny within national parliaments. The focus should be on what administrators do, i.e. on the identification of their tasks and responsibilities, in order to determine the extent to which they facilitate scrutiny. When studying the transnational cooperation of administrative players across Member States, the emphasis would need to be on the tasks of the network of National Parliamentary Representatives in the European Parliament as a permanent coordination mechanism in Brussels, but also on the nascent coordination between EAC secretaries at the margin of COSAC meetings. 


\section{Towards a Typology of National Parliaments}

The objective of this article has been to develop a framework for the study of Europeanization of national parliaments after Lisbon. In this context, Europeanization was understood as the adaptation of national parliaments' internal arrangements and external contacts in order to make effective use of the new system. In particular, the article has addressed two inter-linked questions: What kind of parliaments are likely to Europeanize in reaction to Lisbon, to what extent, and how does this Europeanization express itself?

In the previous sections, we have argued that the effective use of the EWS requires national parliaments to increase the size and role of their bureaucracies and to engage extensively with other national parliaments and European actors. An initial scale for measuring the extent of bureaucratization and transnationalization was developed. Once these two dimensions are combined, nine types of national parliaments emerge, ranging from national parliaments that have a low score on bureaucratization and transnationalization to national parliaments that have a high score on both dimensions.

If bureaucratization and transnationalization are seen as the outcome of Europeanization, then a national parliament's combined score on the two dimensions can be used as a measure of the degree of that national parliament's Europeanization. Thus, a national parliament that has built up an extensive network of contact with other national parliaments and/or European actors and a great administrative capacity to deal with EU affairs is highly Europeanized and will be an active player in EU affairs scrutiny (“active scrutinizer), where as a national parliament that performs average on both dimensions has become somewhat Europeanized. A parliament that has low bureaucratic involvement in the scrutiny of EU affairs and that engages little in cross-border cooperation is only weakly Europeanized and will most likely perform a limited amount of scrutiny ("bystander").

\begin{tabular}{|l|l|l|l|}
\hline Transnationalisation & Low & Medium & \\
\hline Low & & & \\
\hline Medium & "Bystanders" & & \\
\hline High & & & \\
\hline
\end{tabular}

Table 3 Levels of Europeanization (Darker shades indicate higher degrees of Europeanisation) 
However, it is unlikely that all nine types occur in reality or that cases will be evenly distributed across types. Most national parliaments can be expected to have a similar level of development on both bureaucratization and transnationalization (low-low, medium-medium, high-high) and thus be somewhere on the spectrum between bystander and active scrutinizer. As we have discussed in the previous section, transnationalization is linked to some extent to bureaucratization. Before a parliament can actively contribute to discussions with other actors, it has to have the capacity to scrutinize legislation and develop viewpoints. A certain bureaucratic capacity would thus be a requirement for transnationalization. For that reason, we do not expect to find national parliaments with a high level of transnationalization and a low level of bureaucratization. We also do not expect to find the reverse, low transnationalization coinciding with high bureaucratization. One can conceive of two reasons for a low level of transnationalization. Firstly, a national parliament may have little interest in EU affairs. In that case, extensive investment in bureaucratic capacity is unlikely. Secondly, a national parliament may focus on the domestic context of EU affairs, i.e. on mandating the national government. As such a strategy creates a power struggle between parliament and government, issues will be very politicized. While bureaucratic actors may still be needed to provide expertise, it is unlikely that they would be given a high degree of responsibility - i.e. play what we have termed a 'steering role'. They can be expected to perform a service role (provision of advice), which depending on the extent, may corresponds to a low or medium level of bureaucratization. 


\section{Concluding remarks}

Strengthening the role of national parliaments has since Laeken been seen as one of the ways of addressing the EU's fragile democratic legitimacy, and the reforms contained in the Lisbon Treaty have provided a number of measures towards this aim. This article has focused on the extent to which the organization and work of national parliaments is likely to be affected by the Treaty of Lisbon, examining the way in which the performance of national parliaments in making use of their new powers will depend on their capacity, both individually and collectively. National parliaments need to adapt to the changing opportunity structure post-Lisbon, heralding a trend that will see national parliaments undergo processes of Europeanization. The extent of such Europeanization will depend on existing working practices, available resources and the party political context.

In looking more closely at the ensuing dynamics, we identified bureaucratization and transnationalization as the two processes closely linked to Europeanization: national parliaments will confront pressures to build up technical capacity to deal with a larger number of European legislative dossiers, and to network more systematically and within limited time-horizons with chambers in other member states. Both of these pressures are likely to see at least some if not all national parliaments rely to a greater extent on unelected officials who may develop a 'steering role' in the management of EU-related parliamentary affairs. In that regard, the Europeanization of national parliaments leads inevitably back to the question of the effect on the EU's democratic deficit, with the counterintuitive outcome that the Lisbon reforms empower parliamentary bureaucrats rather than elected deputies.

The Europeanization of national parliaments after Lisbon has in recent years become an important concern of a number of scholars, though often with a narrow focus on the functioning of the EWS (e.g. Kiiver, 2012; De Wilde, 2012: Barrett, 2012: Kaczynski, 2011). However, as we have argued here, there is also the need for broader research on the topic such as, for example, the work undertaken by the cross-national research project OPAL (Observatory of Parliaments after the Lisbon Treaty). As part of this project, different teams are currently assessing the bureaucratization (Christiansen et al, 2014) and transnationalization of national parliaments (e.g. Heffler et al, 2014).

Our initial findings point to such a trend of Europeanization leading to a greater bureaucratization of national parliaments (c.f. Högenauer and Neuhold, 2012). This bureaucratization affects both the internal scrutiny of EU legislative documents and first coordination attempts between EAC secretaries. It has thus both a domestic and a transnational dimension. 
The initial impression - yet to be confirmed through more substantive research - here is not encouraging from a democratic theory perspective: whereas the involvement of national parliaments in EU decision-making was meant to reduce the 'democratic deficit' by giving national MPs a greater role in European affairs, it may actually lead to the creation of new bureaucratic networks and thereby empower administrative actors rather than elected representatives. If one takes into account the complexity and the reduced transparency stemming from the inclusion of yet another set of institutions in the EU decision-making process, the potential of the treaty changes to provide a significant improvement regarding the 'democratic deficit' appears to be in question.

Overall, given the limited powers conferred upon national parliaments under the EWS, it is likely, at least in the short- to medium-term, that the 'reverse effect' of the EWS on the work of national parliaments will actually turn out to be stronger than the actual impact that national parliaments will have on the scrutiny of European legislative proposals. ${ }^{\text {iv }}$ At the same time, it seems from the vantage point adopted here that what will be strengthened as a result of these processes is not so much the democratization of the EU, but rather the role of bureaucratic networks facilitating the cooperation among, and the work within, national parliaments in Europe. 


\section{Bibliography}

Arnold, D. (1987) Political Control of Administrative Officials. Journal of Law, Economics, E Organization 3(2): 279-286.

Auel, K. (2005) Introduction: The Europeanization of Parliamentary Democracy. Journal of Legislative Studies 11(3-4): 303-318.

Auel, K. (2006) The Europeanisation of the German Bundestag: Institutional Change and Informal Adaptation. German Politics 15(3): 249-268.

Auel, K. and Benz, A. (2005) The Politics of Adaptation: Europeanisation of National Parliamentary Systems. Journal of Legislative Studies 11(3-4): 372-393.

Baron, F. (2012, forthcoming) Civil servants: how to support the political level: The French Case. In: C. Neuhold, S. Vanhoonacker and L. Verhey (eds.) Civil Servants and Politics. Basingstoke: Palgrave, in press.

Barret, G. (2012). The Early Warning Systems: Some Early Reflections. Presented at Parliaments in the European Union after Lisbon. 23-24 February, Maastricht, the Netherlands.

Benz, A. (2007) Accountable Multilevel Governance by the Open Method of Coordination?. European Law Journal 13(4): 505-522.

Berg, C, Van den (2011) Transforming for Europe. The Reshaping of National Bureaucracies in a system of multi-level governance, Leiden: Leiden University Press.

Börzel, T. (2002) Pace-Setting, Foot-Dragging, and Fence-Sitting: Member State Responses to Europeanization. JCMS 40(2): 193-214.

Börzel, T., Risse, T. (2003).Conceptualizing the Domestic Impact of Europe. In: K. Featherstone and C. Radaelli (eds.) The Politics of Europeanization. Oxford: Oxford University Press, pp. $55-78$.

Christiansen, T., Högenauer A., Neuhold C. (under contract) Parliamentary Administrations in the European Union. Basingstoke: Palgrave Macmillan.

Cooper, I. (2006) The Watchdogs of Subsidiarity: National Parliaments and the Logic of Arguing in the EU. JCMS 44(2): 281-304. 
Cooper, I. (2012) A 'Virtual Third Chamber' for the European Union? National parliaments after the Treaty of Lisbon. West European Politics, 35(3): 441-465.

COSAC (2008), Nineth bi-annual report: Development in European Union Procedures and Practices Relevant to Parliamentary Scrutiny. http://www.cosac.eu/documents/bi-annualreports-of-cosac/.

Damgaard, E. and Jensen, H. (2005) Europeanisation of Executive-Legislative Relations: Nordic Perspectives. Journal of Legislative Studies 11(3-4): 394-411.

De Ruiter, R. (2010) EU soft law and the functioning of representative democracy: the use of method of open coordination by Dutch and British parliamentarians. Journal of European Public Policy 17 (6) 874-89o.

De Wilde, P. (2012). Why the Early Warning System Does not Alleviate the Democratic Deficit. Presented at Parliaments in the European Union after Lisbon. 23-24 February, Maastricht, The Netherlands.

Dimitrakopoulos, D. (2001) Incrementalism and Path Dependence: European Integration and Institutional Change in National Parliaments. JCMS 39(3): 405-22.

Dobbels, M. and Neuhold C. (2012) The Roles Bureaucrats Play': The Input of European Parliament (EP) Administrators into the Ordinary Legislative Procedure: A Case Study Approach, Journal of European Integration, DOI:10.1080/07036337.2012.689832.

Egeberg, M., Gornitzka, A., Trondal, J. and Johannessen, M. (2012) Parliament Staff: Unpacking the Behaviour of Officials in the European Parliament, Journal of European Public Policy, DOI: 10.108o/13501763.2012.718885, pp. 1-20.

European Council (2001), Laeken Declaration on the Future of the European Union, http://european-convention.eu.int/pdf/lknen.pdf.

Gailmard, S. (2002) Expertise, Subversion and Bureaucratic Discretion. JLEO 18(2): 536-555.

Gailmard, S. and Patty, J (2007) Slackers and Zealots: Civil Service, Policy Discretion, and Bureaucratic Expertise. American Journal of Political Science 51(4): 873-889.

Goetz (2000) Europeanisation and national executives: a cause in search of an effect. West European Politics, 23(4): 211-231. 
Hansen, T. and Scholl, B. (2002) Europeanization and Domestic Parliamentary Adaptation - A Comparative Analysis of the Bundestag and the House of Commons. European Integration Online Papers 6(15).

Harmsen, R. (1999) The Europeanization of National Administrations: A Comparative Study of France and the Netherlands. Governance 12(1): 81-113.

Hefftler, C., Neuhold, C., Rozenberg, O., Smith, J, Wessels, W. (under contract) (eds): The Palgrave Handbook of National Parliaments and the European Union, London: Palgrave, Macmillan.

Högenauer A., Neuhold C. (2012), National Parliaments After Lisbon: Administrations on the Rise? UACES General Conference, Passau: 3-5 September.

Holzhacker R. (2007), Parliamentary Scrutiny. In: P. Graziano, M. Vink. Europeanization: New Research Agendas. Basingstoke: Palgrave Macmillan, pp. 141-53.

Huber, J. (2000) Delegation to civil servants in parliamentary democracies. European Journal of Political Research 37(3): 397-413.

Kaczynski, P. (2011) Paper tigers or sleeping beauties? National Parliaments in the post-Lisbon European Political System. Europe. Brussels, 2011.

Kassim, H. (2003), The National Co-ordination of EU Policy: Must Europeanisation Mean Convergence?. In: K. Featherstone and C.M. Radaelli (eds.) The Politics of Europeanisation: Theory and Analysis. Oxford: Oxford University Press, pp. 83-111.

Kiiver, P. (2006) The National Parliaments in the European Union: A Critical View on EU Constitution-Building. The Hague: Kluwer Law International.

Kiiver, P. (2011) The Early-Warning System for the Principle of Subsidiarity: The National Parliament as a Conseil d'Etat for Europe. European Law Review 36: 98-108.

Kiiver, P. (2012) The Early Warning System for the Principle of Subsidiarity. Constitutional theory and empirical reality. London and New York: Routledge.

Knill, C. (2001) The Europeanisation of National Administrations. Patterns of Institutional Change and Persistence. Cambridge: Cambridge University Press.

Knill, C. and Lehmkuhl, D. (2002) The National Impact of European Union Regulatory Policy: Three Europeanization Mechanisms. European Journal of Political Research 41(2): 255-80. 
Ladrech, R. (1994) Europeanization of Domestic Politics and Institutions: The Case of France. JCMS 32(1): 69-88.

Laursen, F. (2005) The Role of National Parliamentary Committees in European Scrutiny: Reflections Based on the Danish Case. Journal of Legislative Studies, 11(3-4): 412-427.

March, J.G., Olsen, J.P. (1984) The New Institutionalism: Organizational Factors in Political Life. American Political Science Review 78(3): 734-749.

Maurer, A. and Kietz, D. (2004) Die neuen Rechte der nationalen Parlamente: Umsetzungsprobleme und Empfehlungen. SWP Diskussionspapier.

Maurer, A., Wessels, W. (eds) (2001) National parliaments on their ways to Europe: Losers or latecomers?. Baden-Baden: Nomos.

McCubbins and Schwartz (1984) Congressional oversight overlooked: Police patrols versus fire alarms. American Journal of Political Science 28: 16-79.

Miklin, E., and Crum, B., (2011) Inter-Parliamentary Contacts of Members of the European Parliament. Report of a Survey. RECON Online Working Paper 2011/o8, Oslo: ARENA Centre for European Studies.

Moe, T. (1990) Political Institutions: The Neglected Side of the Story. Journal of Law, Economics $\mathcal{E}$ Organization 6: 213-253.

Moravcsik, A. (1995) Why international cooperation strengthens national executives: The case of the European Community. Paper presented at the ECSA Conference; 1995, Charleston, SC.

Neuhold, C., Vanhoonacker, S. and Verhey, L. (2012 forthcoming) Civil Servants and Politics. Basingstoke: Palgrave.

Neunreither, K. (2006) Elected legislators and their unelected assistants in the European Parliament. Journal of Legislative Studies, 8(4): 40-6o.

Norton, P. (ed.) (1996) National parliaments and the European Union. London: Frank Cass.

O’Brennan, J. and Raunio, T. (2007) National parliaments within the enlarged European Union. London: Routledge.

Olsen, J. (1997), European Challenges to the Nation State. In: B. Steunenberg and F. van Vught (eds.) Political Institutions and Public Policy. Amsterdam: Kluwer Academic Publishing, pp. 157-88. 
Olsen, J. (2005) Maybe it is time to rediscover bureaucracy Journal of Public Administration Research and Theory 16(1): 1-24.

Page, E. and Jenkins, B. (2005) Policy Bureaucracy: Government With a Cast of Thousands. Oxford: Oxford University Press.

Radaelli, C.M. (2003) The Europeanization of Public Policy. In: K. Featherstone and C.M. Radaelli (eds.) The Politics of Europeanization. Oxford: Oxford University Press, pp. 27-56.

Raunio, T. (1999), Always One Step Behind? National Legislature and the European Union, Government and Opposition, Vol 34(2), pp. 180-202.

Raunio, T. (2007) National legislatures and the Constitutional Treaty. In: J. O’Brennan and T. Raunio (eds.) National Parliaments within the Enlarged European Union: From 'victims' of integration to competitive actors?. Abingdon: Routledge, pp. 79-92.

Raunio, T. (2009) National Parliaments and European Integration: What We Know and Agenda for Future Research. Journal of Legislative Studies 15(4): 317-334.

Raunio, T. (2010) Destined for Irrelevance? Subsidiarity Control by National Parliaments, Europe Working Paper 36/2010, Real Instituto Elcano.

Raunio, T. and Wiberg M. (2009), How to Measure the Europeanisation of a National Legislature? Scandinavian Political Studies, Vol. 33(1), pp. 74-92.

Risse, T., Green Cowles, M. and Caporaso, J.A. (2001) Europeanization and Domestic Change: Introduction. In: M. Green Cowles, J.A. Caporaso and T. Risse (eds.) Transforming Europe. Europeanization and Domestic Change. Ithaca, NY: Cornell University Press, pp.1-2.

Rothenberger, S. and Vogt, O. (2007) The "Orange Card": A Fitting Response to National Parliaments' Marginalisation in EU Decision-Making?. Paper presented at the WSP Conference "Fifty Years in Interparliamentary Cooperation", 13 June, Berlin.

Weber (1978) [1922] Economy and Society (G. Roth and C. Wittich, eds.). Berkeley CA: University of California Press.

Weber-Panariello, P.A. (1995) Nationale parlamente in der Europäischen Union. Baden-Baden: Nomos.

Winzen, T. (2011) Technical or Political? An Exploration of the Work of Officials in the Committees of the European Parliament. Journal of Legislative Studies 17(1): 27 - 44 . 
Wishart, I. (2012) 'Right to Strike' law withdrawn. European Voice 13 March, http://www.europeanvoice.com/article/imported/-right-to-strike-lawwithdrawn/75103.aspx.

Woldendorp J., Keman H., Budge I. (2000), Party Government in 48 Democracies (1945-1998), Dordrecht, Kluwer Academic Publishers. 


\section{Authors}

Thomas Christiansen is Jean Monnet Professor of European Institutional Politics at the Faculty of Arts and Social Sciences, Maastricht University, The Netherlands. He is Executive Editor (with Simon Duke) of the Journal of European Integration, co-editor (with Sophie Vanhoonacker) of the 'European Administration Governance' book series at Palgrave Macmillan and member of the board of the Research Committee on European Unification of the International Political Science Association (IPSA-RC3). He has published widely on various aspects of the institutional politics of the European Union.

Anna-Lena Högenauer is an NWO-funded Postdoctoral Researcher at the Faculty of Arts and Social Sciences, Maastricht University. She is a member of the OPAL project (Observatory of Parliaments after the Lisbon Treaty), which is funded by the NWO, ESRC, ANR and DFG. She is working on the representation of regions and national parliaments in the European Union.

Christine Neuhold is Associate Professor of European Governance within the Department of Political Science, Faculty of Arts and Social Sciences, Maastricht University. She is Director of the Research Master European Studies and Co-coordinator (with Sophie Vanhoonacker) of an Initial Training Network on Dynamics of Inter-institutional Cooperation in the EU (INCOOP), financed by the EU. She has published widely on different aspects of EU policy-making and on EU institutions.

\footnotetext{
${ }^{\mathrm{i}}$ In the case of the area of freedom, security and justice (Article 76 TFEU), the threshold is a quarter of the votes.

${ }^{\text {ii }}$ Cf.COSAC (2008) for a review of all Treaty changes affecting national parliaments.

iii See also Huber (2000).

iv This is notwithstanding the fact that in mid-2012 a 'yellow card' was issued for the first time through the EWS system. While the legislative proposal under dispute was withdrawn, the Commission claims that this was the result of member state resistance more generally and the precise impact of the yellow card remains disputed (Wishart, 13/03/2012, European Voice).
} 